Observed Mass Balance of

Mountain Glaciers and Greenland

Ice Sheet in the 20th Century and

the Present Trends

\author{
Review Article \\ Author(s): \\ Ohmura, Atsumu \\ Publication date: \\ 2011-09
}

Permanent link:

https://doi.org/10.3929/ethz-b-000159871

Rights / license:

In Copyright - Non-Commercial Use Permitted

Originally published in:

Surveys in Geophysics 32(4-5), https://doi.org/10.1007/s10712-011-9124-4 


\title{
Observed Mass Balance of Mountain Glaciers and Greenland Ice Sheet in the 20th Century and the Present Trends
}

\author{
Atsumu Ohmura
}

Received: 30 November 2010/Accepted: 1 April 2011/Published online: 12 May 2011

(C) Springer Science+Business Media B.V. 2011

\begin{abstract}
Glacier mass balance and secular changes in mountain glaciers and ice caps are evaluated from the annual net balance of 137 glaciers from 17 glacierized regions of the world. Further, the winter and summer balances for 35 glaciers in 11 glacierized regions are analyzed. The global means are calculated by weighting glacier and regional surface areas. The area-weighted global mean net balance for the period 1960-2000 is $-270 \pm 34 \mathrm{~mm} \mathrm{a}^{-1}$ w.e. (water equivalent, in mm per year) or $\left(-149 \pm 19 \mathrm{~km}^{3} \mathrm{a}^{-1}\right.$ w.e.), with a winter balance of $890 \pm 24 \mathrm{~mm} \mathrm{a}^{-1}$ w.e. $\left(490 \pm 13 \mathrm{~km}^{3} \mathrm{a}^{-1}\right.$ w.e. $)$ and a summer balance of $-1,175 \pm 24 \mathrm{~mm} \mathrm{a}^{-1}$ w.e. $\left(-647 \pm 13 \mathrm{~km}^{3} \mathrm{a}^{-1}\right.$ w.e. $)$. The linear-fitted global net balance is accelerating at a rate of $-9 \pm 2.1 \mathrm{~mm} \mathrm{a}^{-2}$. The main driving force behind this change is the summer balance with an acceleration of $-10 \pm 2.0 \mathrm{~mm} \mathrm{a}^{-2}$. The decadal balance, however, shows significant fluctuations: summer melt reached its peak around 1945 , followed by a decrease. The negative trend in the annual net balance is interrupted by a period of stagnation from 1960s to 1980s. Some regions experienced a period of positive net balance during this time, for example, Europe. The balance has become strongly negative since the early 1990s. These decadal fluctuations correspond to periods of global dimming (for smaller melt) and global brightening (for larger melt). The total radiation at the surface changed as a result of an imbalance between steadily increasing greenhouse gases and fluctuating aerosol emissions. The mass balance of the Greenland ice sheet and the surrounding small glaciers, averaged for the period of 1950-2000, is negative at $-74 \pm 10 \mathrm{~mm} \mathrm{a}^{-1}$ w.e. $\left(-128 \pm 18 \mathrm{~km}^{3} \mathrm{a}^{-1}\right.$ w.e. $)$ with an accumulation of $297 \pm$ $33 \mathrm{~mm} \mathrm{a}^{-1}$ w.e. $\left(519 \pm 58 \mathrm{~km}^{3} \mathrm{a}^{-1}\right.$ w.e. $)$, melt ablation $-169 \pm 18 \mathrm{~mm} \mathrm{a}^{-1}$ w.e. $\left(-296 \pm 31 \mathrm{~km}^{3} \mathrm{a}^{-1}\right.$ w.e. $)$ calving ablation $-181 \pm 19 \mathrm{~mm} \mathrm{a}^{-1}$ w.e. $\quad(-316 \pm$ $33 \mathrm{~km}^{3} \mathrm{a}^{-1}$ w.e.) and the bottom melt- $21 \pm 2 \mathrm{~mm} \mathrm{a}^{-1}$ w.e. $\left(-35 \pm 4 \mathrm{~km}^{3} \mathrm{a}^{-1}\right.$ w.e. $)$. Almost half $\left(-60 \pm 3 \mathrm{~km}^{3} \mathrm{a}^{-1}\right)$ of the net mass loss comes from mountain glaciers and ice caps around the ice sheet. At present, it is difficult to detect any statistically significant trends for these components. The total mass balance of the Antarctic ice sheet is considered to be too premature to evaluate. The estimated sea-level contributions in the twentieth
\end{abstract}

\footnotetext{
A. Ohmura $(\bowtie)$

Institute for Atmospheric and Climate Science, Swiss Federal Institute of Technology (E.T.H.),

Universitätsstrasse 16, 8092 Zürich, Switzerland

e-mail: ohmura@env.ethz.ch
} 
Century are $5.7 \pm 0.5 \mathrm{~cm}$ by mountain glaciers and ice caps outside Antarctica, $1.9 \pm 0.5 \mathrm{~cm}$ by the Greenland ice sheet, and $2 \mathrm{~cm}$ by ocean thermal expansion. The difference of $7 \mathrm{~cm}$ between these components and the estimated value with tide-gage networks $(17 \mathrm{~cm})$ must result from other sources such as the mass balance of glaciers of Antarctica, especially small glaciers separated from the ice sheet.

Keywords Mass balance $\cdot$ Greenland $\cdot$ Mountain glaciers · Trends

\section{Introduction}

The net influx of mass from glaciers to the ocean is one of the major components of the sea level changes. Presently, about 200,000 glaciers (Ohmura 2009a) are estimated to exist outside Greenland and Antarctica. The total glacierized surface and the ice volume on the planet are estimated at $16.2 \times 10^{6} \mathrm{~km}^{2}$ and $28.4 \times 10^{6} \mathrm{~km}^{3}$ (Ohmura 2009a), respectively. The total glacier ice on the planet is $65 \mathrm{~m}$ sea level equivalent. With respect to the surface area, $86 \%$ is on Antarctica, $11 \%$ on Greenland and $3 \%$ in other regions. In terms of ice volume, $89 \%$ is on Antarctica, $10 \%$ on Greenland and less than $0.35 \%$ in other regions (Ohmura 2009a). The glacier ice distribution is newly evaluated and presented in Table 1.

The main data source is the World Glacier Inventory (WGI) as presented in Ohmura (2009a). About 110,000 glaciers archived in WGI are individually treated in the following calculations, instead of the gridded approach taken by Radic and Hock (2010). The main point of Table 1 is the new evaluation of the regional glacier area and ice volume for 27 regions outside Greenland and Antarctica. These 27 regions are defined to be associated with the WGI working groups. In 16 regions the regional inventories are completed. We have detailed information on all glaciers in these regions including the surface area. In the remaining 11 regions, the degree of the WGI completion rate varies from the half-done stage like Bhutan to zero like Mexico and Indonesia. The information for the untouched regions is due to literature of various regional studies (Ohmura 2009a). For partially completed regions, the total glacier areas of the regions are estimated by multiplying the inventoried area by the ratio of 100 to the percent of the completion rate. This approximation holds only when the area frequency distribution of the inventoried glaciers is identical to that of all glaciers. The global area of glaciers and ice caps is computed as $550 \times 10^{3} \mathrm{~km}^{2}$. This result is practically identical to $546 \times 10^{3} \mathrm{~km}^{2}$ by Dyurgerov and Meier (2005), but considerably smaller than $704 \times 10^{3} \mathrm{~km}^{2}$ by Hock et al. (2009). This difference is due to the fact that Hock et al. (2009) includes glaciers and ice caps on Greenland $\left(54 \times 10^{3} \mathrm{~km}^{2}\right)$ and Antarctica $\left(132 \times 10^{3} \mathrm{~km}^{2}\right)$. The material in Hock et al. (2009) yields after calculation the global area of glaciers and ice caps outside Greenland and Antarctica as $518 \times 10^{3} \mathrm{~km}^{2}$.

The glacier ice volume was estimated for individual glaciers with the area/depth equation by Chen and Ohmura (1990). For the partially completed regions, the total ice volume of inventoried glaciers was multiplied by the reciprocal of the completion rate, as for the total area. The global total ice volume of glaciers and ice caps outside Greenland and Antarctica by way of the Chen/Ohmura equation is $100.3 \times 10^{3} \mathrm{~km}^{3}$ (28 $\mathrm{cm}$ sea level equivalent), while it is $131.8 \times 10^{3} \mathrm{~km}^{3}$ (36 cm sea level equivalent) by the Bahr equation (Bahr et al. 1997). Comparing the computed volumes against the recent observations of actual glacier volumes with Ground Penetrating Radar, the Chen/Ohmura equation tends to underestimate the volume for smaller glaciers (area less than $100 \mathrm{~km}^{2}$ ), but the Bahr equation tends to overestimate the volumes of larger glaciers. The reality may lie between 
Table 1 Glacier area, ice volume, mean thickness and World Glacier Inventory completion rate (Antarctica is due to Fujii 2006)

\begin{tabular}{lllll}
\hline Region & $\begin{array}{l}\text { Surface area } \\
\left(10^{3} \mathrm{~km}^{2}\right)\end{array}$ & $\begin{array}{l}\text { Ice volume } \\
\left(10^{3} \mathrm{~km}^{2}\right)\end{array}$ & $\begin{array}{l}\text { Mean } \\
\text { thickness }(\mathrm{m})\end{array}$ & $\begin{array}{l}\text { WGI complete } \\
\text { rate in } \%\end{array}$ \\
\hline Greenland & 1,748 & 2,931 & 1,677 & NA \\
Iceland & $\mathbf{1 1 . 2 0 0}$ & $\mathbf{3 . 6 5}$ & $\mathbf{3 2 6}$ & $\mathbf{1 0 0}$ \\
Scandinavia & $\mathbf{3 . 1}$ & $\mathbf{0 . 1 6 7}$ & $\mathbf{5 3 . 9}$ & $\mathbf{1 0 0}$ \\
Alps & $\mathbf{3 . 1}$ & $\mathbf{0 . 1 4 6}$ & $\mathbf{4 7 . 1}$ & $\mathbf{1 0 0}$ \\
Pyrenees and Cordillera Cantabrica & $\mathbf{0 . 0 1 1}$ & $\mathbf{1 0}-\mathbf{4}$ & $\mathbf{1 0}$ & $\mathbf{1 0 0}$ \\
Jan Mayen & 0.116 & $10^{-2}$ & 25 & 0.0 \\
Svalbard & $\mathbf{3 3 . 7}$ & $\mathbf{7 . 6 6}$ & $\mathbf{2 2 7 . 3}$ & $\mathbf{1 0 0}$ \\
Zemlya Frantsa Yosifa & $\mathbf{1 3 . 7 5 9}$ & $\mathbf{1 . 9 0 7}$ & $\mathbf{1 3 8 . 6}$ & $\mathbf{1 0 0}$ \\
Novaya Zemlya & $\mathbf{2 3 . 6 4 5}$ & $\mathbf{1 1 . 1 3 3}$ & $\mathbf{4 7 0 . 8}$ & $\mathbf{1 0 0}$ \\
Severnaya Zemlya \& Ostrov Ushakova & $\mathbf{1 9 . 3 6 6}$ & $\mathbf{6 . 6 0 3}$ & $\mathbf{3 4 1 . 0}$ & $\mathbf{1 0 0}$ \\
Ostrava de Longa, Novosibirskiye Ostrova & $\mathbf{0 . 0 8 1}$ & $\mathbf{0 . 0 0 7}$ & $\mathbf{8 6 . 4}$ & $\mathbf{1 0 0}$ \\
Ostrov Vrangelya & $\mathbf{0 . 0 0 4}$ & $\mathbf{0 . 0 0 0 0 3 3}$ & $\mathbf{8 . 3}$ & $\mathbf{1 0 0}$ \\
Caucasus & $\mathbf{1 . 3 9 0}$ & $\mathbf{0 . 0 6 6}$ & $\mathbf{4 7 . 5}$ & $\mathbf{1 0 0}$ \\
Severniy Ural & $\mathbf{0 . 0 1 8}$ & $\mathbf{0 . 0 0 0 3 7}$ & $\mathbf{2 0 . 6}$ & $\mathbf{1 0 0}$ \\
Ex-SU in Asia & $\mathbf{2 3 . 8 5 5}$ & $\mathbf{4 . 2 1 7}$ & $\mathbf{1 7 6 . 8}$ & $\mathbf{1 0 0}$ \\
Canadian Arctic Islands & 151.758 & 27.56906 & 181.8 & 17.3 \\
North America (continental,excl. Alaska) & 49.609 & 4.5825 & 92.3 & 21.3 \\
Alaska & 74.722 & 20.45017 & 273.6 & 16.4 \\
Mexico & 0.011 & & & 0.0 \\
Afganistan, Iran, Turkey & 4.044 & 0.14569 & 36.0 & 11.7 \\
India, Pakistan & 40.000 & 3.07622 & 76.9 & 4.7 \\
Bhutan, Nepal & 7.340 & 0.74046 & 100.9 & 40.7 \\
China & $\mathbf{5 9 . 4 2 5}$ & $\mathbf{5 . 6 0 0}$ & $\mathbf{9 4 . 2}$ & $\mathbf{1 0 0}$ \\
Indonesia & 0.007 & & & 0.0 \\
Africa & 0.011 & $10^{-4}$ & 10 & 0.0 \\
New Zealand & $\mathbf{1 . 1 5 8}$ & $\mathbf{0 . 0 6 2}$ & $\mathbf{5 3 . 5}$ & $\mathbf{1 0 0}$ \\
South America & 25.855 & 1.9432 & 75.2 & 17.9 \\
Sub-Antarctic islands & 7 & 1.2 & 171.4 & 0.0 \\
Antarctica & 13,860 & 25,400 & 1,833 & NA \\
Total & 16,158 & 28,432 & 1,760 & \\
Of which outside Antarctica \& Greenland & 550.241 & 100.926 & 183 & \\
\hline Botd & & & \\
& & & & \\
& & &
\end{tabular}

Bold figures are based on completed World Glacier Inventory (WGI), while regular figures are due to partially done WGI

these values. The main reason for this uncertainty is mainly due to the poor completion rate of WGI for regions of many glaciers, such as Alaska and Canadian Arctic Islands. The completion of the WGI will contribute tremendously to close the gap of our present knowledge. Although the glaciers outside Greenland and Antarctica are a minority in terms of surface area and ice volume, they are located mostly in mild climate zones, and respond rapidly to climate changes. The present article aims at presenting the mass balance and its variations during the last century for the glaciers and ice caps outside Greenland and Antarctica. Further, the mass balance variations will be explained with climatic conditions 
of the last 100 years. The contemporary snapshot mass balance of Greenland glaciers is also estimated. It is considered premature to apply similar considerations to Antarctica at present.

\section{The Method for Estimating the Global Mass Balance}

The major portion of the glacier mass exchanges takes place at the surface. The surface mass balance of glaciers is evaluated commonly through three methods: a stake method, geodetic method and hydrological balance method. The stake method relies on the in situ measurement of the mass variation at stakes fixed on the glacier surface. The density of the stake network is preferred to be denser than 1 stake per one square kilometer (Funk 1985) for middle sized Alpine glaciers with area in the order of $10 \mathrm{~km}^{2}$. This is the most direct approach and will remain the most trusted method. The geodetic method obtains the mass change by evaluating the elevation change of the entire glacier surface between two discrete times. A comparison of the stake and the geodetic methods (Haug et al. 2009; Huss et al. 2009) sometimes yields large differences, which helps finding errors efficiently in one or both of the measurements. This method is of increasing importance with the satellite data especially for larger glaciers. Further, the satellite-based geodetic method is suited for estimating calving rate, which is difficult to measure with the other methods. Under the hydrological method one measures precipitation, evaporation and discharge from a glacierized basin, and attributes the rest to the mass balance of the glacier. Ideally, all three methods should be applied for a glacier. Stake method and hydrological method are applied in most projects in the Alps and Scandinavia. All three methods have been used for more than 30 year only for Vernagtferner (data: personal communication by L. Braun) in the Austrian Alps.

If careful measurements are carried out with sufficient stake density, the estimated error of the mean specific net balance of a glacier could remain within 90-280 mm water equivalent (w.e.) $\mathrm{a}^{-1}$ (Huss et al. 2009). Dyurgerov (2002) quotes as a typical uncertainty $200 \mathrm{~mm} \mathrm{a}^{-1}$. Therefore, $200 \mathrm{~mm} \mathrm{a}^{-1}$ is taken as a representative error by the stake measurement for an entire glacier. This estimation gives an error of $34 \mathrm{~mm} \mathrm{a}^{-1}$ for the global mean net balance.

The present work is exclusively based on the mass balance measurements carried out with the stake method, and the stress is given to those glaciers, which have separate summer and winter balance observations. The data set is an updated version of the set that was made for the International Union of Geodesy and Geophysics (IUGG) Workshop on Changing Planet 2003 (Ohmura 2004). The data set of 2003 was made based on the World Glacier Monitoring Service (WGMS) mass balance archive, supplemented by the personal data collections by R. Braithwaite and A. Ohmura, and those glaciers in Dyurgerov (2002). All these four data files had glaciers, which were not included in the other collections. These glaciers were extracted from each collection and merged to the largest file of WGMS, to form the maximum mass balance data collection. This maximum data collection has been annually updated by the author, through the contributions by many mass balance observers and also by tracing individual publications where mass balance data are published. Presently, there are almost 400 glaciers where some form of mass balance measurement was carried out, including the measurement of only one hydrological year. In view of large year-to-year variations, it is necessary to continue the measurement at least for 5-10 years just to obtain a snapshot situation of the mass balance. There are about 160 glaciers, which satisfy this condition. To obtain a mass balance trend similar to that of the 


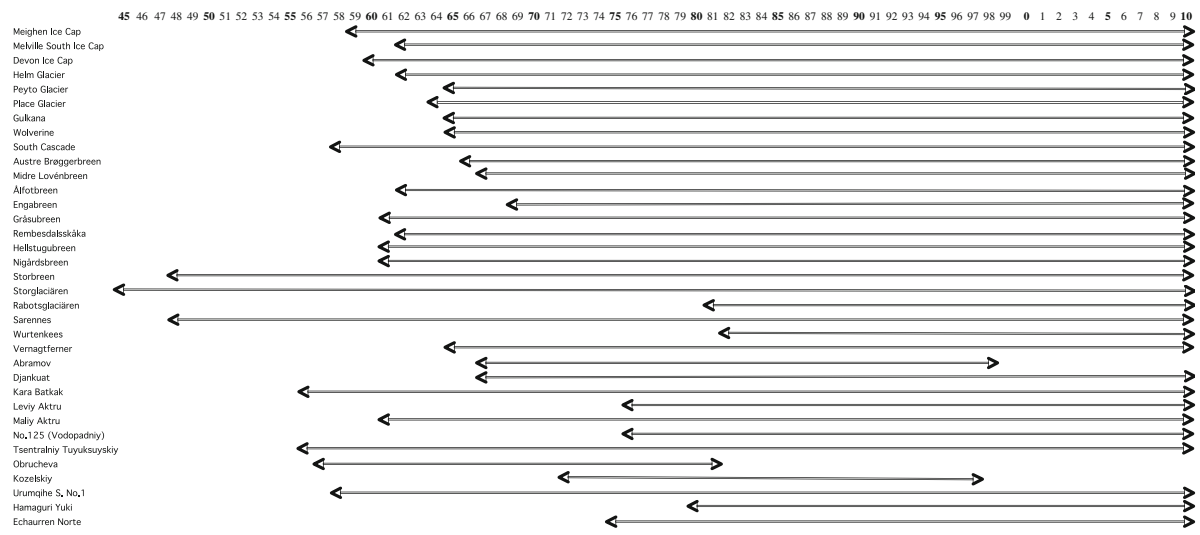

Fig. 1 Duration periods of 35 glaciers in the world, which kept annual observations of winter (Bw) and annual (Bn) mass balances for more than 30 years. Bs is usually calculated from $\mathrm{Bw}$ and $\mathrm{Bn}$

climate, 30 years or longer observations are needed. There are slightly more than 50 glaciers with observation records longer than 30 years. Further, in order to understand the cause of the change of mass balance, the accumulation and the ablation must be separately determined for the same period. Except for the glaciers in the equatorial and monsoonal regions, the accumulation and the ablation can be substituted by the winter and summer balances which are easier to measure. There are presently 35 glaciers world wide with the observations of separate winter and summer balances lasting for more than 30 years. The duration periods of these important 35 glaciers are summarized in Fig. 1. All of these glaciers are located in the Northern Hemisphere. Further, most of these 35 glaciers have limited winter accumulation, a necessity to avoid an excessively long fieldwork in spring and also to avoid avalanche danger. None of these glaciers is calving glaciers. This selectiveness may introduce a certain sampling bias in calculating global total mass balance. Meier et al. (2007) discuss the role of the calving loss of glaciers and ice caps for some glaciers in Alaska and Russian Arctic islands, but the error due to the biased sampling at the global scale is at present hard to quantify.

Because of the data scarcity, the mass balance data are sometimes augmented with the estimated mass balance, usually expressed as functions of meteorological observations (e.g. Meier 1984). This approach has, however, not been taken in the present work, as one of the goals of the present work is to understand how the climatic conditions affect the mass balance changes. Only glacier mass balances determined with the stake method are used. The net balance will be compiled with respect to 17 glacierized regions of the world. The global mean mass balance will then be calculated by giving the weight of the surface areas of each region. For analyzing the winter and summer balances, the number of the glacierized regions is reduced to 11, as the other 6 regions do not have seasonal mass balance observations carried out for the necessary length of time.

\section{Global Net Balance}

From the 17 glacierized regions 137 glaciers were chosen to calculate the annual net balance. From necessity the glaciers with shorter observational records than 30 years are 
also included for the region with poor data coverage. These glaciers are located in the Andes (7), North American Cordillera (24), Canadian Arctic Islands (8), Alaska (4), Kamchatka (2), the Himalayas (4), the Tienshians/Dzungaria (14), Altai (4), Pamir (1), Polar Ural (2), Caucasus (7), the Alps/Pyrenees (21), Iceland (9), Scandinavia (23), Svalbard (5), Severnaya Zemlya (1), and Africa (1). Since the density of the observed glaciers is very inhomogeneous, the surface areas of the glacierized regions were used as weights for calculating the global mean balance. Four regions hold $90 \%$ of the weight, the Canadian Arctic Islands, Alaska, the North American Cordillera, and Svalbard. In the previous section the likely error for the annual mass balance of a single glacier is taken as $50 \mathrm{~mm} \mathrm{a}^{-1}$. The major source of this error is not the measurement error at a single stake, but the sampling error due to the limited number of stakes. Assuming that a similar magnitude of errors might creep in when calculating regional means, and further for obtaining the area-weighted global mean, a rough estimate of the error for the global mass balance is set at $90 \mathrm{~mm} \mathrm{a}^{-1}$. Lemke et al. (2007) sets the error at $102 \mathrm{~mm} \mathrm{a}^{-1}$. The result of the regional and global mass balance estimation is presented in Fig. 2. Although the short-term variations of the annual net balance is large, all regions show a common trend for decadal intervals. The area-weighted global mean mass balance of the last half-century shows a negative balance with an accelerating trend. This type of analysis has become possible since the International Geophysical Year (IGY, 1957-1958). It appears that the end of the 1950s and the early 1960s captured the last stage of the large loss of mass.

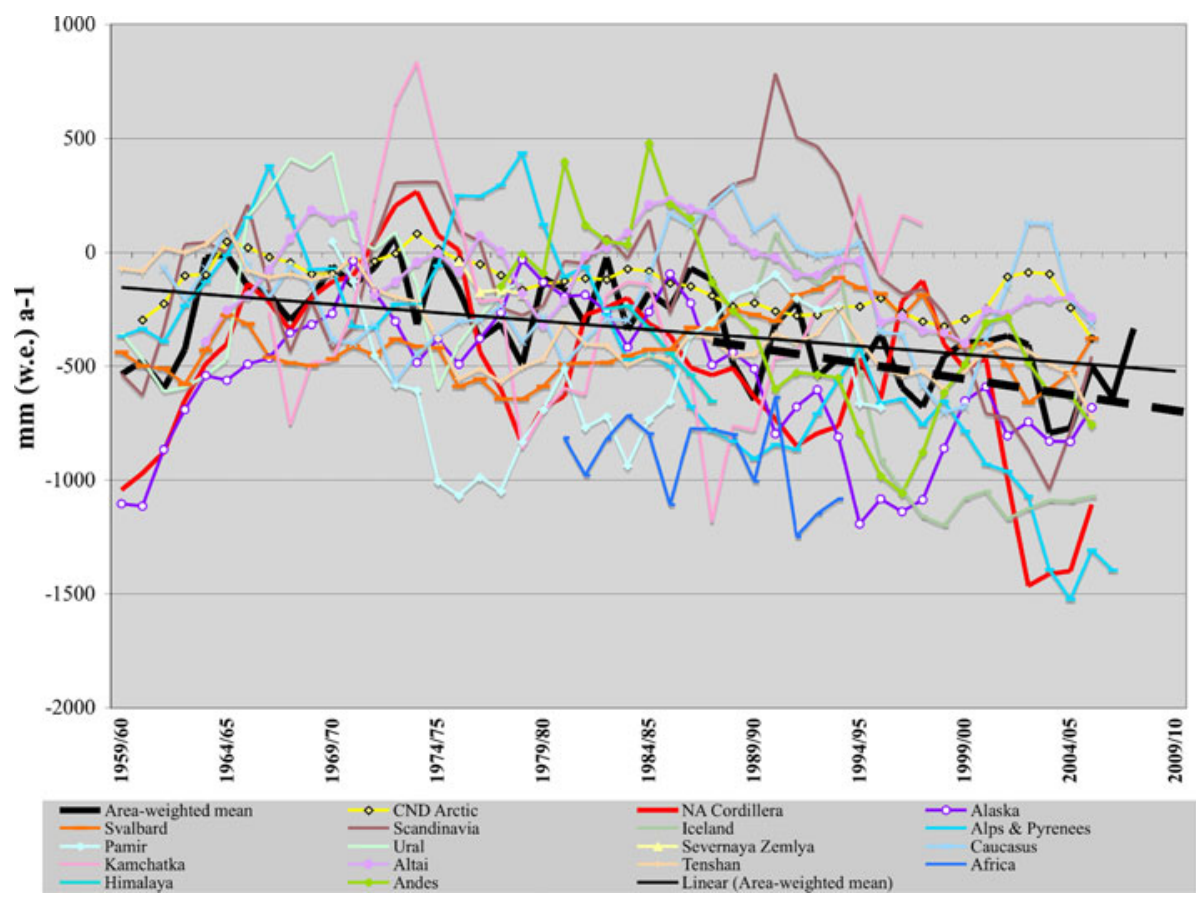

Fig. 25 year running means of the annual mean net balance for 50 years for the following 17 regions: Arctic Canada, North American Cordillera, Alaska, Svalbard, Scandinavia, Iceland, Alps, Pamir, Urals, Severnaya Zemlya, Caucasus, Kamchatka, Altaishan, Tienshan/Dzungaria, Africa, the Himalayas, the Andes. The bold black line indicates the area-weighted global mean, while the two black straight lines indicate the accelerations for the periods of the last 50 years 1961-2010 (thin line) and for the last 20 years 1991-2010 (thick broken ilne) 
It is not certain if there was a period of global large mass loss before this period, as the global observational coverage did not exist before IGY. This problem will be reexamined later in this section with mass balance observations carried out in Europe. Starting in the mid-1960s until late 1980s the global mean mass balance became close to the equilibrium characterized with only a minor negative balance, $-215 \pm 34 \mathrm{~mm}$ (w.e.) $\mathrm{a}^{-1}$. The end of the 1980s marks the transition to a large negative balance culminating at $-605 \pm 34 \mathrm{~mm}$ (w.e.) $\mathrm{a}^{-1}$ (mean of 2006-2008) after 2005. The half-century mean global net balance was $-270 \pm 34 \mathrm{~mm}$ (w.e.) $\mathrm{a}^{-1}$. The pentade global mean net balance is summarized in Table 2 together with winter and summer balances, which are the theme of the following section. The mean global balance since 1960 can be compared with the most recent IPCC Assessment Report 4 (Lemke et al. 2007), which presents $-283 \mathrm{~mm}$ (w.e.) $\mathrm{a}^{-1}$.

Table 2 Area-weighted global mean winter (Bw), summer (Bs) and annual (Bn) mass balances of 35 glaciers from 11 regions, arranged for pentade means

\begin{tabular}{lrrll}
\hline Pentade period & Bw & \multicolumn{1}{l}{ Bs } & Bn & Bn 137 glaciers \\
\hline $1960 / 1961-1964 / 1965$ & 685 & -848 & -163 & -131 \\
$1965 / 1966-1969 / 1970$ & 835 & $-1,068$ & -233 & -132 \\
$1970 / 1971-1974 / 1975$ & 881 & $-1,048$ & -167 & -140 \\
$1975 / 1976-1979 / 1980$ & 944 & $-1,166$ & -222 & -247 \\
$1980 / 1981-1984 / 1985$ & 1,003 & $-1,144$ & -141 & -232 \\
$1985 / 1986-1989 / 1990$ & 914 & $-1,260$ & -346 & -332 \\
$1990 / 1991-1994 / 1995$ & 885 & $-1,353$ & -468 & -317 \\
$1995 / 1996-1999 / 2000$ & 984 & $-1,374$ & -389 & -426 \\
$2000 / 2001-2004 / 2005$ & 892 & $-1,292$ & -400 & -444 \\
\hline
\end{tabular}

The last column is the pentade means of the annual balance including the glaciers with only annual balance observations. Unit is $\mathrm{mm}$ w.e. $\mathrm{a}^{-1}$. The range of uncertainty for Bw and Bs is estimated at $24 \mathrm{~mm} \mathrm{a}^{-1}$, and that for $\mathrm{Bn}$ is $34 \mathrm{~mm} \mathrm{a}^{-1}$

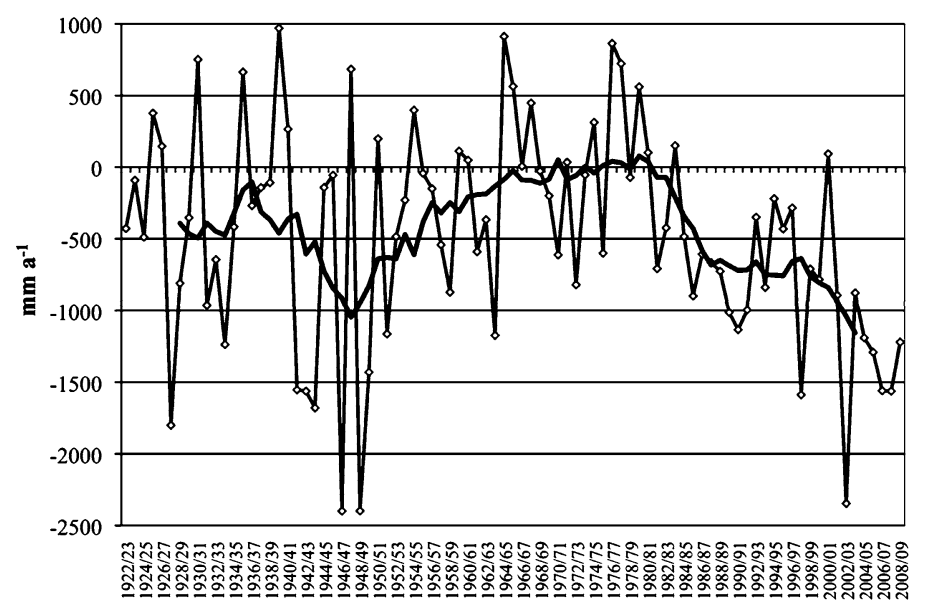

Fig. 3 Mean annual net balance of 20 glaciers in the Alps and the Pyrenees. The black bold line indicates a 11-year running mean. Unit in $\mathrm{mm}$ w.e. $\mathrm{a}^{-1}$ 
The trend of the mass loss has been accelerating at a rate of $-9 \pm 2.1 \mathrm{~mm} \mathrm{a}^{-2}$ during the last 50 years and $-15 \mathrm{~mm} \mathrm{a}^{-2}$ during the last 20 years. Meier et al. (2007) presents the acceleration of $-22 \mathrm{~mm}$ (w.e.) $\mathrm{a}^{-2}$ for 10 years from 1996 to 2006.

To supplement the unavailable global information of the earlier period, the works on glaciers in Europe were used. The mean annual net balance for 19 glaciers from the Alps and 1 glacier from the Pyrenees is presented in Fig. 3. The figure shows a period of large mass loss starting in late 1930s, centered on 1948 and lasting until the late 1950s. It appears that the brief period of large negative balance depicted in the global mean at the end of 1950s in Fig. 2 probably captured the last glimpse of the large mass loss in the midcentury. It must be clarified how these variations were caused. To do this one needs seasonal mass balance in order to look at the accumulation and ablation separately.

\section{Seasonal Mass Balance}

There are 35 glaciers located in 11 regions for which winter and summer balances were measured for more than 30 years. The area-weighted winter, summer and annual balances are presented in Fig. 4 for the period of the last half-century. The upper line (blue) represents the winter balance, which is a good approximation of accumulation. The lower line (red) is the summer balance, an indicator of the melt. The black line in the middle is the annual net balance for the 35 glaciers. The annual net balance of the 35 glaciers is compared with the annual net balance (brown line) computed with 137 glaciers from the 17 glacierized regions. The closeness of the two lines representing the annual net balance indicates that the net balance computed with 35 glaciers represents fairly well the global

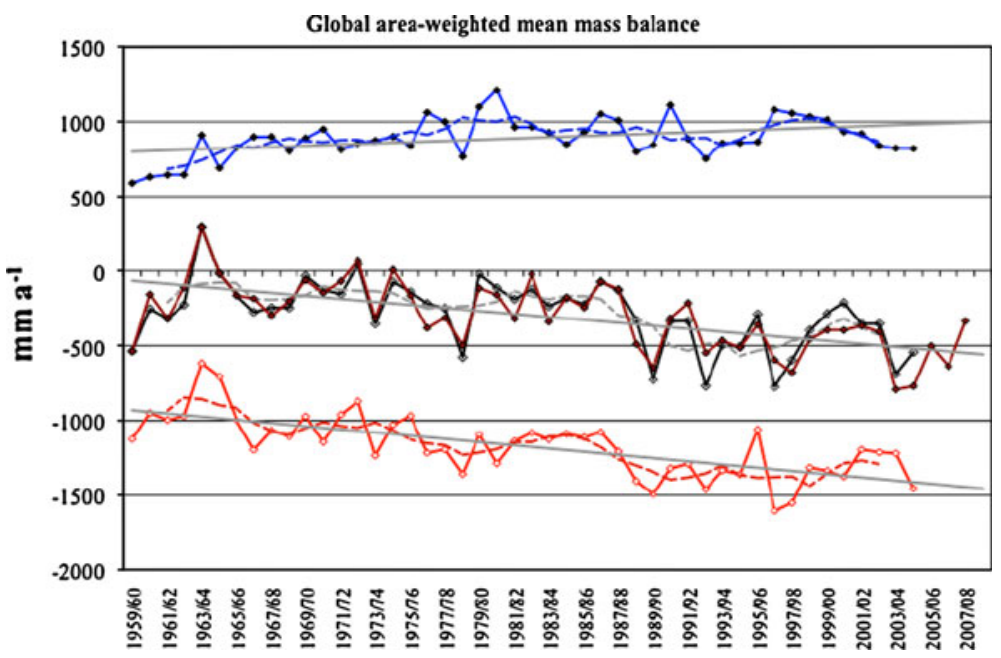

Fig. 4 Area-weighted global mean annual mass balance, based on 35 glaciers in 11 regions. Blue, brown and red lines indicate winter, annual and summer balances, respectively. Broken lines indicate 11 year running means in each category. Further, black lines in the middle indicating the mean annual net balance are those for 137 glaciers in 17 regions, for comparison. The closeness between the brown and black lines supports the global significance of the 35 glaciers from 11 regions, on which winter and summer balances are observed. These 11 regions are Arctic Canada, North American Cordillera, Alaska, Svalbard, Scandinavia, Alps, Pamir, Caucasus, Kamchatka, Altaishan, Tienshan/Dzungaria. Unit in mm w.e. $a^{-1}$ 
mean conditions. The broken lines accompanying the three lines are the 11-year running means, while the three grey straight lines indicate the linear trend of the 50 years.

The decrease in ablation in the late early 1960s, stagnation from the early 1960s to the mid-1980s, and the sudden increase in the late 1980s are the most important episodes in the decadal variation in the global summer balance. The winter balance (accumulation) indicates also a long-term variation, increasing from the late 1950s to the mid-1980s. Accumulation and melt appear weakly correlated until the mid-1980s. This tendency has been broken since the late 1980s and the accumulation has clearly been declining during the last decade. Overall, the range of variability for the accumulation is much smaller than that for the melt ablation. The 50-year trend as well as the decadal variation of the global annual net balance depicted in the previous section is to a great extent dictated by the change in the melt ablation. This analysis shows that globally averaged the decadal variation of the net balance is to $90 \%$ determined by the change in ablation. The mean annual net balance of the last half-century was $-270 \pm 34 \mathrm{~mm}$ (w.e.) $\mathrm{a}^{-1}$. The mean accumulation and ablation were $890 \pm 24 \mathrm{~mm}$ (w.e.) $\mathrm{a}^{-1}$ and $-1,175 \pm 24 \mathrm{~mm}$ (w.e.) $\mathrm{a}^{-1}$, respectively. The accelerations of net balance, accumulation and ablation are $-9 \pm 2.1$ $\mathrm{mm}$ (w.e.) $\mathrm{a}^{-2},+0.7 \pm 2.0 \mathrm{~mm}$ (w.e.) $\mathrm{a}^{-2}$ and $-10 \pm 2.0 \mathrm{~mm}$ (w.e.) $\mathrm{a}^{-2}$, respectively.

\section{Long-Term Mass Balance of Glaciers in the Alps and Scandinavia and its Causes}

The longest observations of glacier mass balance and climate are available only in Europe. Two glaciers in Scandinavia, Storglaciären (mass balance observation starting in 1945/1946, data: personal communication by P. Jansson) and Storbreen (starting in 1948/1949, data: Kjøllmoen 2010) were chosen to represent Scandinavia, as these glaciers possess the longest seasonal mass balance observations. For the Alps, Glacier de Sarennes (starting in 1948/1949, data: personal communication by C. Vincent) was chosen. Further, annual net balance of the Aletchgletscher (starting in 1922/1923, data: personal communication by A. Bauder) and the summer mass balance of the Lower Stake of the Claridenfirn (starting in 1914/1915, data personal communication by H. Müller) are added. Fig. 5 presents the above-mentioned 5 curves with their 11 year running means. It appears that during the 1920s the annual mass balance was close to zero and the glaciers were at equilibrium with the climate. Summer ablation started to increase at the end of the 1910 s and formed a period of strong ablation lasting for 20 year, centered on 1945. This period was the time of the largest mass loss that was only matched by the last decade of the twentieth century. After 1960, ablation decreased towards the beginning of the 1980s. At the beginning of the1980s the annual net balance approached zero. With the onset of the present century the ablation, hence negative annual net balance showed a rather sudden increase that was not matched by any other periods of the observation era. The decadal variation of the winter accumulation was small, but not insignificant. In the main it fluctuated proportional to the air temperature, except for the last decade, as the accumulation started to decrease. This was due to the decrease of solid precipitation under higher temperature. The period of the last 100 years can be characterized by the two periods of near equilibrium or slight positive balance (beginning of the twentieth century, and 1970s) and two periods of large mass loss (early 1940s to early 1950s, and the present day after 1995).

The general trend of the summer ablation can be interpreted in terms of air temperature. Fig. 6 represents the summer 3 months' (JJA) temperature measured in the glacier regions of Europe, three in Scandinavia and three in the Alps. The course of temperature in the 


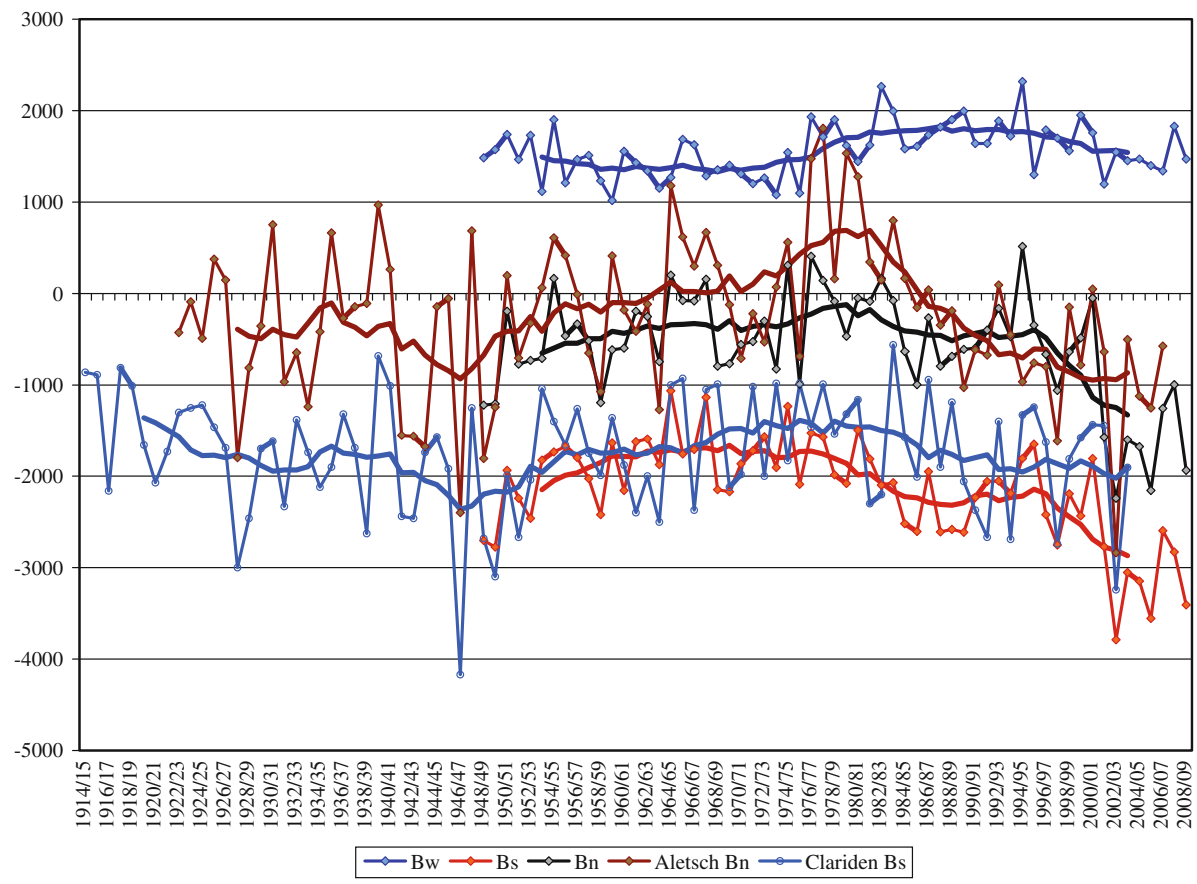

Fig. 5 Mean mass balance for the Alps and Scandinavia. The mean annual balances are the arithmetic means of the three glaciers, Storglaciären, Storbreen and Glacier de Sarennes. There are three shorter lines (for the period 1948/1949-2008/2009) marked with diamonds, from the top in dark blue, black and red indicating winter, annual and summer balances, respectively. The annual net balance for the Aletschgletscher is plotted for the period of 1922/1923-2005/2006 with a brown curve. The light blue curve ticked with circles is the summer balance at the lower stake on Claridenfirn, indicating the summer melt for the period of 1914/2005-2003/2004, near the equilibrium line. The smooth curves running through them in the same colours are 11 year running means. Unit in mm w.e. $\mathrm{a}^{-1}$

glacierized regions of Europe resembles closely that of the global mean, except that the range of the temperature fluctuation is about three times larger in the glacierized areas. A close examination, however, shows that during the 1940s larger ablation was happening under lower temperature in comparison with the modern warm period. This can only be explained by considering the long-term change in solar radiation (Ohmura et al. 2007).

The decadal variability the solar radiation at the earth's surface in a continental and global scale has only recently been acknowledged. Fig. 7 illustrates the course of the global solar radiation observed at five sites in Europe. Solar radiation fluctuated over the range of $14 \mathrm{Wm}^{-2}$ during the course of the last 90 years. Solar radiation was large during the 1940s and 1950s. Then, it decreased steadily during the following 30 years towards the late 1980s, which was followed by a rather sharp increase after late 1980s. These decreasing and increasing phases are often referred to as global dimming and brightening. One should, however, bear in mind that there was also an earlier brightening period during the 1940s and 1950s. The modern brightening period does not match the first brightening period of 1940s and 1950s. The change in the earth's surface global solar radiation was explained by Ohmura (2009b) through the direct and indirect effects of aerosol. Combining the incoming long-wave radiation and solar radiation, the change in the total incoming radiation was negative at least from 1955 until 1985, causing the climate cooling and small 


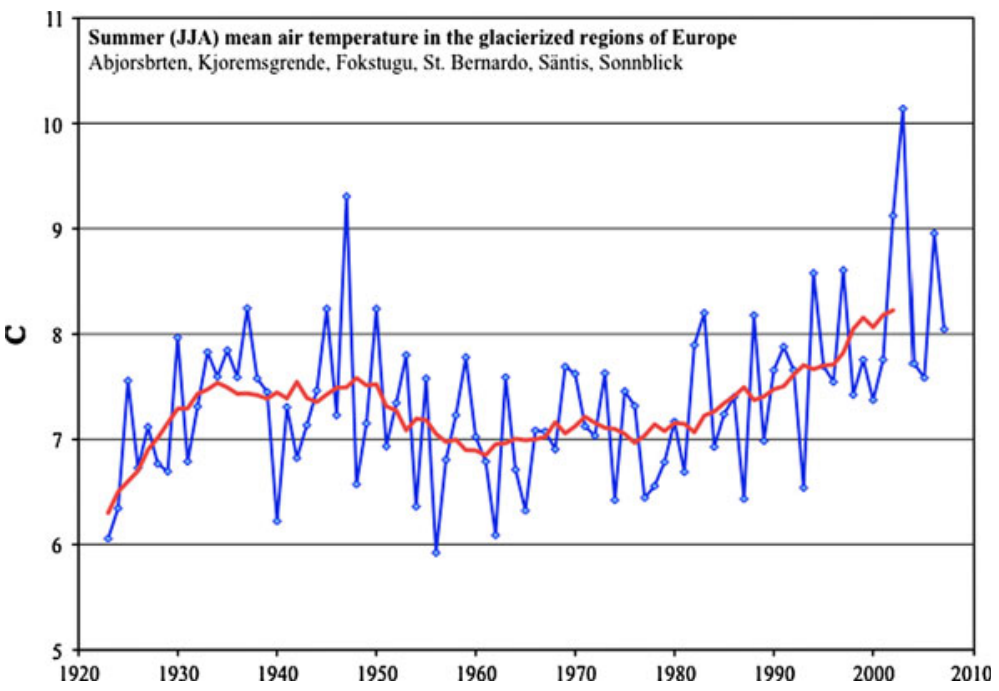

Fig. 6 Summer air temperature for the glacierized region of Europe. The blue line represents the mean values of the six stations, Abjorsbraten (601 m a.s.1.), Kjoremsgrende (626 m a.s.1.) and Fokstugu (972 $\mathrm{m}$ a.s.1.) of Norway, St. Bernardo (1,639 m a.s.l.) and Säntis (2,490 m a.s.1.) of Switzerland, and Sonnblick (3,105 m a.s.1.) of Austria for June, July and August. The red line is the 11-year running mean

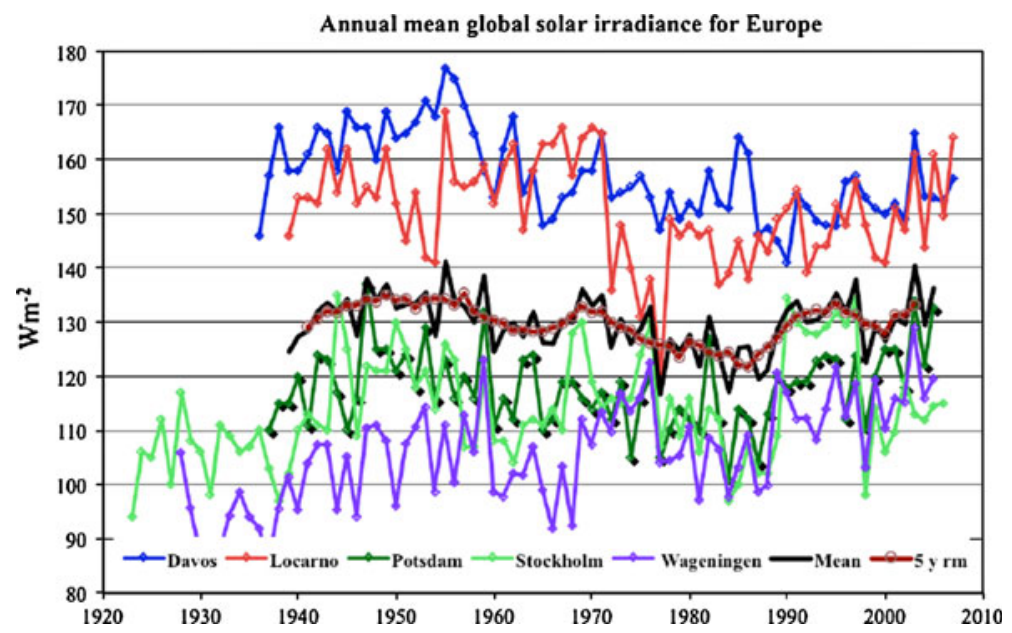

Fig. 7 Mean annual global solar radiation for 5 European sites (Stockholm, Wageningen, Davos, Potsdam and Locarno-Monti) with the longest observation records. The black line in the middle indicates the mean of the five stations, while the brown line ticked with circles is the 11-year running mean of the European mean curve

ablation. Increasing long-wave and solar radiation after 1985 is the reason for the rapid melt of the last two decades. The mass loss of the last decade took over that of the 1940s, not only due to the higher temperature, but also due to the decreasing accumulation and the rapidly increasing solar radiation (Ohmura et al. 2007; Huss et al. 2009). 
There is an effort to relate the mass balance of European glaciers with respect to the fluctuation in the North Atlantic sea surface temperature (SST), which is referred to as Atlantic Multidecadal Oscillation (AMO). AMO was originally proposed by R. Newell (personal communication in 1985) indicating the SST fluctuation in the North Atlantic with about a 50-year periodicity. The cause of the fluctuation is explained by the ocean circulation fluctuation by Delworth and Mann (2000). The relationship between AMO, cloud amount and solar global radiation in Europe was reported earlier by Ohmura and Lang (1989). Recently Ohmura (2006, 2009a) found a similar variation of solar global radiation in North America and Northern Pacific. The correlation between AMO and negative glacier mass balance is not a cause and effect relationship, but both North Atlantic SST and larger glacier melt are caused by the same process, namely the change in solar global radiation as detailed in the present section.

\section{Mass Balance of Greenland}

The ice-covered area of Greenland $\left(1,748 \times 10^{3} \mathrm{~km}^{2}\right)$ comprises $82 \%$ of the total surface area of Greenland $\left(2,164 \times 10^{3} \mathrm{~km}^{2}\right)$. The total ice volume is estimated at 2,620 $\times 10^{3}$ $\mathrm{km}^{3}$ (Weidick 1995), which is equivalent to $6.7 \mathrm{~m}$ sea level without considering the effect of hydro-isostasy. About $97 \%$ of the surface area of glaciers on Greenland is made up by the ice sheet $\left(1,694 \times 10^{3} \mathrm{~km}^{2}\right)$, and the remaining $3 \%$ by mountain glaciers and ice caps $\left(53.73 \times 10^{3} \mathrm{~km}^{2}\right)($ Calanca et al. 2000; Hock et al. 2009). Most mountain glaciers and ice caps in Greenland occupy the regions near the coast and the lower altitudes. Consequently, the ablation from these small glaciers through melt and calving is large. The mass balance of these small glaciers is important for the mass balance of entire Greenland, as the ablation area $\left(161 \times 10^{3} \mathrm{~km}^{2}\right)$ of the ice sheet accounts for only $9.5 \%$ of the ice sheet area (Ohmura et al. 1999). In the present section the snapshot mass balance of glaciers in Greenland will be estimated. The relevant period for this estimation is the second half of the twentieth century, as the main sources of the data are from investigations carried out since the IGY (e.g. Benson 1962).

The accumulation (substituted by winter balance) and ablation (substituted by summer balance) on Greenland glaciers have been rarely observed for more than 8 years consecutively at the same locations. The exceptions are GISP2/Summit (3,150 m a.s.1.), Swiss Camp (1,155 m a.s.l.) and 4 traverse lines of Geological Survey of Greenland and Denmark in the lower elevation sites (ranging from 200 to 1,100 $\mathrm{m}$ a.s.1.) in the southwest Greenland ice sheet. Although the annual and seasonal mass balance observations at these sites are valuable, other methods must be used to complete the full coverage of the ice sheet and glaciers. Snow pits and ice core studies offer useful information on accumulation in the dry snow and upper percolation zones of the accumulation area in accordance with the Benson (1961) and Müller (1962) definitions. The accumulation data obtained since Benson (1962) are much denser than those for Antarctica, and are used by various authors for estimation of the accumulation of the Greenland ice sheet (Reeh and Olesen 1986; Ohmura and Reeh 1991; Ohmura et al. 1999; Calanca et al. 2000; Bales et al. 2009). The accumulation in the lower percolation, superimposed ice and ablation zones must be estimated, as the ice core from these zones suffers at least from a partial loss of the mass. The estimation adopted in the present work is the interpolation between the accumulations observed in the lowest area of the upper percolation zone and the solid precipitation observed at meteorological stations outside the glaciers. In total monthly precipitation data from 42 meteorological stations were used. The observed precipitation values were 
corrected against the observational errors with the Sevruk method (Sevruk 1986). The Sevruk correction method is a simple function expressing the rate of the snowfall underestimation as a function of wind speed, using the WMO absolute standard snow gauge (Busch precipitation gauge) as the standard. Actual mathematical forms are slightly different for each national standard snow gage. The merit of this method is that it does not over-correct the measured values, avoiding overestimations, a problem of many similar correction methods. There is a substantial investigation of the Danish standard Hellmann gauge behind the Sevruk method.

The melt ablation was calculated using the empirical relationship between the summer balance and the mean air temperature of the summer 3 months (JJA) proposed by Ohmura et al. (1996). The monthly temperature used for the calculation was taken from Ohmura (1987). The physical justification of the use of air temperature for the melt estimation is provided by Ohmura (2001). To ensure high accuracy it is essential to project the temperature distribution on a realistic topographic map, as the melt takes place in a narrow marginal zone where both contour lines and isothermal lines tend to be concentrated. The Ekholm $2 \times 2 \mathrm{~km}$ digital topographic model (Ekholm 1996) was used as the base for the interpolation.

Ablation due to glacier calving is an important process of mass balance not only for the ice sheet but also for the mountain glaciers and ice caps, many of which are located near and on the coast. The only possibility to obtain the calving rate of the Greenland glaciers is to calculate all calving glaciers individually. Weidick (1995) completed such calculations for south-west coast of Greenland, south of $73^{\circ} \mathrm{N}$. Higgins (1991) did a similar study for the northern shore of Greenland. The mid-east coast was studied by Reeh (1994). The compilation of calving by Reeh et al. (1999) by using all these results appears to this author as the most advanced study on the calving rate from Greenland glaciers and is adopted in the present study.

Error estimations for a continental scale glacier are difficult to quantify (Lemke et al. 2007). Nevertheless, Ohmura et al. (1999) adopted a half of the difference of maximum and minimum of the mean accumulation on EGIG-Line (Expédition Glaciologique Internationale au Groenland) measured by various authors (Benson 1962; Seckel 1977; Tober 1986; Anklin 1991, Anklin et al. 1998) as an indicator of the error. This is a zone with the richest scientific information in Greenland. For the Greenland ice sheet accumulation, it is $12 \%$ or $60 \mathrm{~km}^{3} \mathrm{a}^{-1}$. Hanna et al. (2005) estimates the accumulation error at $5 \%$. In this work the larger error, $12 \%$ has been adopted. It is assumed that the other components, melt ablation and calving loss have an error range of the same order.

The estimation of the mass balance calculation based on the material presented above is summarized in Table 3. The most important conclusion of this evaluation is the fact that the mass balance of Greenland glaciers is already negative at the present time. The annual net balance of $-128 \pm 18 \mathrm{~km}^{3} \mathrm{a}^{-1}$ is equivalent to $+0.35 \pm 0.05 \mathrm{~mm} \mathrm{a}^{-1}$ in sea-level change. The present result can be compared with IPCC AR4 (Lemke et al. 2007) reporting the balance of +25 to $-60 \mathrm{~km}^{3} \mathrm{a}^{-1}$ for period from 1961 to 2003 , and -50 to $-100 \mathrm{~km}^{3}$ $\mathrm{a}^{-1}$ for 1993-2003. The work published after the last Assessment Report, for example Rignot et al. (2008) presents $-123 \pm 58 \mathrm{~km}^{3} \mathrm{a}^{-1}$ for the period of 50 years from 1958 to 2007 , where the recent balance shows a bigger loss, $-212 \pm 41 \mathrm{~km}^{3} \mathrm{a}^{-1}$ for the period of 2001-2007.

Also important is the fact that almost half of this net discharge, $60 \pm 3 \mathrm{~km}^{3} \mathrm{a}^{-1}$ comes from mountain glaciers and ice caps. Hock et al. (2009) presents $22 \pm 59 \mathrm{~km}^{3} \mathrm{a}^{-1}$ for this component. These glaciers, which are not a part of the ice sheet, are located in a maritime climate of the coastal zone of Greenland, having usually larger mean specific accumulation 


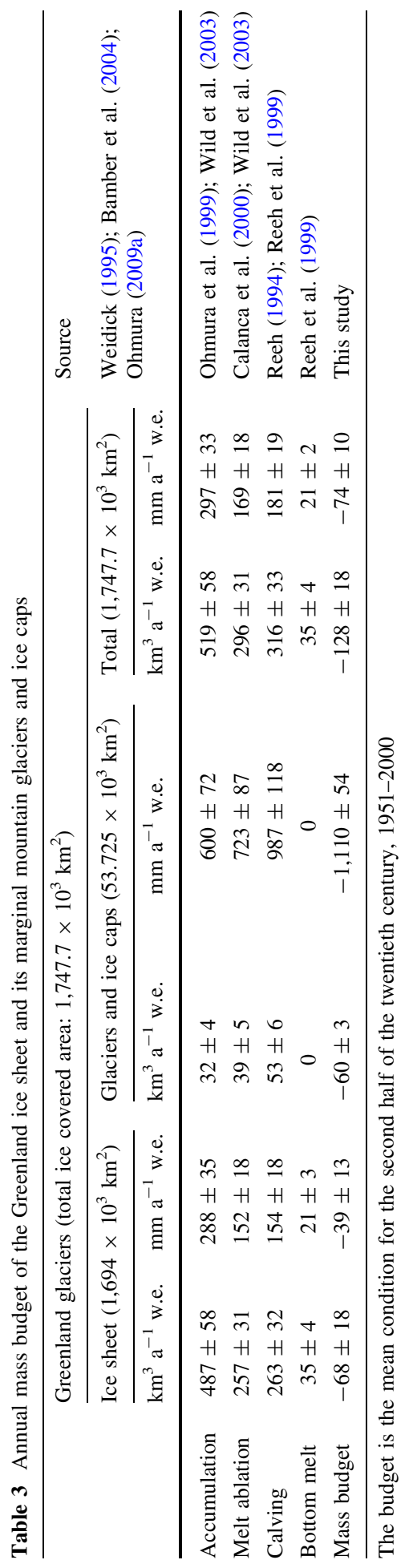


than the ice sheet. As many of these glaciers are located below 1,000 $\mathrm{m}$ a.s.l., specific melt is also large. Many of these glaciers are also calving glaciers, increasing further the total ablation rate. These low-altitude glaciers are also expected to respond quickly to the warming of the climate.

The next important point to investigate is the possibility of temporal variation of the mass balance on Greenland. There are some works reporting an accelerating net mass loss (e.g. Box et al. 2006). There are also reports on expanding melting zones (Abdalati and Steffen 2001). Some reports are directly concerned with the change in shape of the ice sheet (Krabill et al. 2000). These are remote sensing studies based on a relatively short period of investigations spanning from 10 to 15 years. A close examination of the existing direct mass balance measurements presented in the fifth paragraph of the present section shows that an observation period of about 10 years is too short to identify long-term trends. Although there is a possibility of promising advances in these directions, it may still be some time before the temporal change in Greenland's mass balance is numerically presented.

\section{Effect on Sea-Level Change and Conclusion}

The above findings are converted in terms of the sea level change and summarized in Table 4. The most important contribution to sea level rise is made by mountain glaciers and ice caps outside Greenland and Antarctica. These small glaciers occupy only 3.5 and $0.3 \%$ of the total glacier surface and ice volume, respectively. Nevertheless, the largest mass influx comes from these small glaciers, mainly because the ice sheets under the present climate are located in very cold climates, where a slight warming does not yet increase their melt significantly. A similar consideration applies to mountain glaciers and ice caps in Greenland. Their total surface area accounts for only $3 \%$ of the total ice-covered surface on Greenland. Owing mainly to their low altitudes and proximity to the sea, their net mass transfer to ocean almost matches that of the Greenland ice sheet. The total mass flow from all mountain glaciers and ice caps outside Antarctica is equivalent to $57 \mathrm{~mm}$ per century. This result suggests that possible contributions from mountain glaciers and ice caps on Antarctica may also be important.

Based on observations made during the second half of the twentieth century, the contributions to sea level can be accounted for as follows: $57 \pm 5 \mathrm{~mm}$ per century by mountain glaciers and ice caps outside Antarctica; $19 \pm 5 \mathrm{~mm}$ per century by the

Table 4 Estimated sea level changes of the twentieth century and its components

\begin{tabular}{lll}
\hline Components & Unit in mm & Source \\
\hline Mountain glaciers and ice caps & $41 \pm 5$ & This study \\
Greenland ice sheet & $19 \pm 5$ & This study \\
Greenland glaciers and ice caps & $16 \pm 1$ & This study \\
Thermal expansion of ocean & 20 & Based on Levitus et al. (2005) \\
Antarctic ice sheet, glaciers and ice caps, & 74 & This study \\
$\quad$ and other sources & 170 & J. Church (personal \\
Tide gauge interpretation & & communication) \\
\end{tabular}


Greenland ice sheet; $20 \mathrm{~mm}$ per century by thermal expansion of the sea water-totaling $96 \pm 9 \mathrm{~mm}$ per century. Since the tide gauge-based sea-level rise during the twentieth century is $170 \mathrm{~mm}$ per century, the difference of $74 \mathrm{~mm}$ per century must still be accounted for. A part of this gap can be attributed to the mass balance of glaciers and ice caps on Antarctica as suggested by Hock et al. (2009). The small glaciers especially in the milder climatic zones of the Antarctic Peninsula and West Antarctica must be closely investigated.

Acknowledgments The author is indebted to the following colleagues for acquiring pre-publication mass balance data: Miguel Arenillas of Ingeniería 75, S.A., Andreas Bauder and Martin Funk of E.T.H. Zurich, Roger Braithwaite of the University of Manchester, Ludwig Braun of Bavarian Academy of Sciences, Graham Cogley of the University of Trent, Jon Ove Hagen of the University of Oslo, Peter Jansson of Stockholm University, Giovanni Kappenberger of Swiss Federal Office of Meteorology and Climatology, Bjarne Kjølloen of the Norwegian Water Resources and Energy Directorate, Jack Kohler of the Norwegian Polar Institute, Michael Kuhn and Andrea Fischer of the University of Innsbruck, Hans Müller of Tergeso A.G., Wolfgang Schöner of Central Institute for Meteorology and Geodynamics, Christian Vincent of the University of Grenoble, and Michael Zemp of the University of Zurich. The author received valuable help in computational methods for error estimations from Hans-Rudolf Künsch of the Department of Mathematics at E.T.H. Zurich.

\section{References}

Abdalati W, Steffen K (2001) Greenland ice sheet melt extent: 1979-1999. J Geophys Res 106(D24): 33983-33988

Anklin M (1991) $\mathrm{CO}_{2}$-analyse an einem Eisbohrkern aus Zentralgrönland und Bestimmung von Niederschlagsraten entlang einer Fliesslinie mittels $\mathrm{H}_{2} \mathrm{O}_{2}$-analyse. Unpublished Lizentialarbeit, Division of Climate and Environment Physics, Institute of Physics, University of Berne

Anklin M, Bales RC, Mosley-Thompson E, Steffen K (1998) Annual accumulation at two sites in northwest Greenland during recent centuries. J Geophys Res 103(D22):28775-28783

Bahr DB, Meier MF, Peckham SD (1997) The physical basis of glacier volume-area scaling. J Geophys Res 102(B9):20355-20362

Bales RC, Guo Q, Shen D, McConnell JR, Du G, Burkhart JF, Spikes VB, Hanna E, Cappelen J (2009) Annual accumulation for Greenland updated using ice core data developed during 2000-2006 and analysis of daily coastal meteorological data. J Geophys Res 114:D06116. doi:10.1029/2008JD011208

Bamber JA, Payne AJ (eds) (2004) Mass balance of the cryosphere. Cambridge University Press, Cambridge

Benson CS (1961) Stratigraphic studies in the snow and firn of the Greenland Ice Sheet. Folia Geogr Dan 9:13-37

Benson CS (1962) Stratigraphic studies in the snow and firn of the Greenland Ice sheet. Research Report, No. 70, Snow, Ice, and Permafrost Research Establishment (SIPRE)

Box JE, Bromwich DH, Veenhuis LS, Bai L, Stroeve JC, Rogers JC, Steffen K, Haran T, Wang S (2006) Greenland ice sheet surface mass balance variability (1988-2004) from calibrated Polar MM5 output. J Clim 19:2783-2800

Calanca P, Gilgen H, Ekholm S, Ohmura A (2000) Gridded temperature and accumulation distributions for use in cryospheric models. Ann Glaciol 31:118-120

Chen J, Ohmura A (1990) Estimation of Alpine glacier water resources and their change since 1870s. In: Lang H, Musy A (eds) Hydrology in mountainous regions I. IAHS Publ., No. 193, pp 127-135

Delworth TL, Mann ME (2000) Observed and simulated multidecadal variability in the Northern Hemisphere. Clim Dynamics 16:661-676

Dyurgerov M (2002) Glacier mass balance and regime: data of measurements and analysis. Occasional Paper No.55, Institute of Arctic and Alpine Research, Univ. Colorado, Boulder

Dyurgerov M, Meier MF (2005) Glaciers and the changing earth system: a 2004 snapshot. Occasional Paper58, Occasional Paper 58, Institute of Arctic and Alpine Research, University of Colorado, Boulder, CO

Ekholm S (1996) A full coverage, high resolution, topographic model of Greenland computed from a variety of digital elevation data. J Geophys Res 101(B10):21961-21972

Funk M (1985) Räumliche Verteilung der Massenbilanz auf dem Rhonegletscher und Ihre Beziehung zu Klimaelementen. Geograph. Inst., Eidgenössische Techn. Hochsch. Zürich, Zürcher Geographische Schriften, p 24 
Hanna E, Huybrechts P, Janssens I, Cappelen J, Steffen K, Stephens A (2005) Runoff and mass balance of the Greenland ice sheet: 1958-2003. J Geophys Res 110:D13108. doi:10.1029/2004JD005641

Haug T, Rolsrad C, Elvehøy H, Jackson M, Maalen-Johansen I (2009) Geodetic mass balance of the western Svartisen ice cap, Norway, in the periods 1968-1985 and 1985-2002. Ann Glaciol 50(50): $119-125$

Higgins AK (1991) North Greenland glacier velocities and calf ice production. Polarforschung 60(1):1-23

Hock R, de Woul M, Radic V, Dyurgerov M (2009) Mountain glaciers and ice caps around Antarctica make a large sea-level rise contribution. Geophys Res Lett 36:L07501. doi:10.1029/2008GL037020

Huss M, Funk M, Ohmura A (2009) Strong Alpine glacier melt in the 1940s due to enhanced solar radiation. Geophys Res Lett 36:L23501. doi:10.1029/2009GL040789,2009

Kjøllmoen B (ed) (2010) Glaciological investigations in Norway 2009. Norwegian water resources and energy directorate, Oslo, pp. 94

Krabill W, Abdalati W, Frederick E, Manizade S, Martin C, Sonntag J, Swift R, Thomas R, Wright W, Yungel J (2000) Greenland ice sheet: high-elevation balance and peripheral thinning. Science 289: 428-430

Lemke P, Ren J, Alley RB, Allison I, Carrasco J, Flato G, Fujii Y, Kaser G, Mote P, Thomas RH, Zhang T (2007) Observations: changes in snow, ice and frozen ground. In: Solomon S, Qin D, Manning M, Chen Z, Marquis M, Averyt KB, Tignor M, Miller HL (eds) Climate change 2007: the physical science basis. contribution of working group I to the fourth assessment report of the intergovernmental panel on climate change. Cambridge University Press, Cambridge

Levitus S, Antonov J, Boyer T (2005) Warming of the world ocean. Geophys Res Lett 32:L02604. doi: 10.1029/2004GL021592

Meier MF (1984) Contribution of small glaciers to global sea level. Sci 226:1418-1421

Meier M, Dyurgerov MB, Rick UK, O’Neel S, Pfeffer WT, Anderson RS, Anderson SP, Glazovsky AF (2007) Glaciers dominates eustatic sea-level rise in the 21st century. Science 317:1064-1067

Müller F (1962) Zonation in the accumulation area of the glaciers of Axel Heiberg Island, N.W.T. Can J Glaciol 4:302-313

Ohmura A (1987) New temperature distribution maps for Greenland. Zeitschr Gletscherk Glazialgeol 23:1-45

Ohmura A (2001) Physical basis for the temperature/melt-index method. J Appl Meteor 40:753-761

Ohmura A (2004) Cryosphere during the twentieth century. Geophys Monogr 150:239-257 (Am Geophys Union)

Ohmura A (2006) Observed long-term variations of solar irradiance at the earth's surface. Space Sci Rev. doi:10.1007/s11214-006-9050-9 (special edition)

Ohmura A (2009a) Completing the world glacier inventory. Ann Glaciol 50(53):144-148

Ohmura A (2009b) Observed decadal variations in surface solar radiation and their causes. J Geophys Res 114(D00D13). doi:10.1029/2008JD011290

Ohmura A, Lang H (1989) Secular variation of global radiation in Europe. In: Lenoble J, Geleyn J-F (eds) IRS'88: current problems in atmospheric radiation. A. Deepak Publ., Hampton, pp 298-301

Ohmura A, Reeh N (1991) New precipitation and accumulation distribution maps for Greenland. J Glacial 37:140-148

Ohmura A, Wild M, Bengtsson L (1996) A possible change in mass balance of Greenland and Antarctic ice sheets in the coming century. J Clim 9:2124-2135

Ohmura A, Calanca P, Wild M, Anklin M (1999) Precipitation, accumulation and mass balance of the Greenland ice sheet. Zeitschr Gletscherk Glazialgeol 35:1-20

Ohmura A, Bauder A, Müller H, Kappenberger G (2007) Long-term change of mass balance and the role of radiation. Ann Glaciol 46:367-374

Radic V, Hock R (2010) Regional and global volumes of glaciers derived from statistical upscaling of glacier inventory data. J Geophys Res 115. doi:10.1029/2009JF001373

Reeh N (1994) Calving from Greenland glaciers: observations, balance estimates of calving rates, calving laws. In: Reeh N (ed) Workshop on the calving rate of West Greenland glaciers in response to climate change, 13-15 September 1993. Copenhagen, Danish Polar Center, pp 85-102

Reeh N, Olesen OB (1986) Velocity measurements on Daugaard-Jensen Gletscher, Scoresby Sund. East Greenland. Ann Glaciol 8:146-150

Reeh N, Mayer Christoph, Miller H, Thomsen HH, Weidick A (1999) Present and past climate control on fjord glaciations in Greenland: implications for IRD-deposition in the sea. Geophys Res Lett 26 : c1039-1042

Rignot E, Box JE, Burgess E, Hanna E (2008) Mass balance of the Greenland ice sheet from 1958 to 2007. Geophy Res Lett 35. doi:10.1029/2008GL035417 
Seckel H (1977) Höhenänderungen im grönländischen Inlandeis zwischen 1959 und 1968. EGIG 1967-1968 3(5):187, 194 (Medd. Gronland)

Sevruk B (1986) Correction of precipitation measurements: Swiss experience. In: Sevruk B (ed) Correction of precipitation measurements. Zürcher Geographische Schriften, No. 23, pp 187-196

Tober M (1986) Die deutschen geodätischen Arbeiten im Rahmen der internationalen glaziologischen Grönland Expedition (EGIG) 1959-1974. Deutsche Geodätische Kommission Reihe B, Nr. 281, Bayerische Akademie der Wissenschaften, München, pp 63-84

Weidick A (1995) Greenland. Satellite image atlas of glaciers of the world, professional paper, 1386-C, U.S. Geol. Survey, U.S. Gov. Printing Office, Washington, DC

Wild M, Calanca P, Scherrer SC, Ohmura A (2003) Effects of polar ice sheets on global sea level in highresolution greenhouse scenarios. J Geophys Res 108(D5):4165, ACL 5-1-10 